\title{
First-year students' experience of a WebQuest to explore the University's online resources and virtual learning environment
}

\author{
Paula Barnard-Ashton, BSc OT (Wits), MSc OT (Wits) \\ Manager and Lecturer; eFundanathi - Learn with Us; School of Therapeutic Sciences, Faculty of Health Sciences, University of the \\ Witwatersrand. Affiliated to the Department of Occupational Therapy
}

Janine van der Linde, B OT (UFS), MSc OT (Wits)

Lecturer and Instructional Designer eFundanathi - Learn with Us; School of Therapeutic Sciences, Faculty of Health Sciences, University of the Witwatersrand. Affiliated to the Department of Occupational Therapy

\begin{abstract}
Alan Rothberg, MBBCh (Wits), FCPaed (SA), PhD (Wits)
Associate Professor; School of Therapeutic Sciences, Faculty of Health Sciences, University of the Witwatersrand
\end{abstract}

Patricia Mclnerney, BSc Nursing (Wits), Dip N Ed (Wits), MSc Nursing (Wits), PhD (Wits)

Associate Professor, Centre for Health Science Education, Faculty of Health Sciences, University of the Witwatersrand

First-year students present with diverse digital literacy skills. Orientation to online tools and resources via a WebQuest was introduced as a novel modality to allow students to work at their own pace. Occupational therapy and physiotherapy students $(N=383)$ over three consecutive academic years completed the WebQuest. A descriptive survey design was used to investigate the students' electronic media preferences and their perceptions of the WebQuest. The students $(n=250)$ reported preference for personal computing and home-based internet, and rated their electronic media proficiency as very good. The WebQuest was seen as beneficial to their learning and the difficulty level of the WebQuest was "just right". The majority of the students felt that the WebQuest made the learning process more interesting, but were more ambivalent regarding their enjoyment of the WebQuest, possibly due to technical issues and experiencing it as being time consuming. Overall the WebQuest was a successful modality for orientating the students to the online tools and resources of the University.

Key words: WebQuest; blended learning; e-learning; digital literacy; occupational therapy; physiotherapy

\section{INTRODUCTION}

Typically, students enter the higher education environment with a diversity of computing and technology experience due to varied high school exposure and socio-economic circumstances ${ }^{1,2}$. It is therefore important to establish their digital literacy and access to technology to ensure their readiness for the Blended Learning $(\mathrm{BL})$ components of the curriculum ${ }^{1,3}$. Students should also be orientated to the online tools and resources available at the University during the initial weeks of their first year to ensure they all have equal understanding and skill for participating in academic tasks $^{3}$. Traditionally the first-year occupational therapy and physiotherapy students have been attending an orientation workshop in a computer laboratory which takes them step-by-step through how to access and use the Virtual Learning Environment (VLE), the online library resources, anti-plagiarism software and their student email accounts. During the orientation workshops, the proficient students tended to be bored with having to wait for others to catch up, and the inexperienced students were stressed by perceived pressure to hurry up when they did not understand the work. It became obvious that the step-by-step, face-to-face approach was frustrating most of the students. The opportunities afforded by using a WebQuest were explored as a possible way to 'practice what we preach' by using interactive e-learning in the orientation session.

\section{Blended Learning and Digital Literacy}

Blended Learning (BL) is widely considered to be the integration of traditional face-to-face teaching methods with e-learning activities in a coordinated manner to address the learning outcomes of a course ${ }^{3,4}$. Health science education has adopted BL as a strategy to address the intense learning demands of the rapid technological advancement and ever-expanding knowledge within the health professions ${ }^{5}$. Blended Learning as an active learning style is thought to improve a students' critical and analytical thinking, application of new knowledge in clinical practice and reflective practice for higher order thinking ${ }^{4}$. Ocak and Topal ${ }^{5}$ found that $\mathrm{BL}$ in an anatomy course allows for anywhere, any-time access to resources, which facilitated students' freedom to control their learning. Despite some students being limited by poor internet connectivity, they were generally positive about the BL course and were comfortable with BL being introduced in other courses. Evidence suggesting improved student performance in courses implementing BL is growing, particularly when correlating active participation in the online activities such as engagement in online discussion forums, with student assessment ${ }^{6-8}$. A frequently cited concern in the implementation of $B L$ courses however, is the digital literacy skills of the students?.

Papageorgiou and Callaghan' critiqued the marginalisation of some students entering the South African higher education system due to poor technology preparedness created by inequality within 
the high school system despite two decades of post-apartheid democracy and development. They strongly advised academics to be aware of advantaging some students and marginalising others when introducing information technology-dependent curricula, and recognise that students will need to develop these skills in order to cope in their professions once qualified. Snowball and Mostert ${ }^{3}$ supported this concern when introducing $B L$ as a response to the teaching and learning demands created by massification. Their study recommended the evaluation of student digital literacy skills on admission, and the provision of additional support where needed. They demonstrated that first-year students' skills developed rapidly, and uptake of participation on the VLE peaked prior to assignment and examination dates.

Digital literacy can impact online reading literacy. Wu and Peng ${ }^{10}$ found that teenagers who had good online navigation skills and engaged in purposeful information-seeking habits while online, were more likely to have better online reading literacy than those who engaged in more social online behaviours. Pak "' became concerned with the digital literacy skills of her students who were typically from low socio-economic backgrounds. Of particular note was her observation that while modern students are proficient in social media related skills, this does not correlate with academic digital ability. She created a WebQuest to address this gap within the context of an English language course. Leung and Unal' ${ }^{12}$ found that WebQuests support the development of digital literacy, irrespective of the topic and content, further supporting this teaching strategy.

\section{What is a WebQuest?}

The concept of the WebQuest was pioneered by Dodge ${ }^{13}$ as a tool to make online learning more engaging and efficient for students. Dodge's most cited definition is: "A WebQuest is an inquiry-oriented activity in which some or all of the information that learners interact with comes from resources on the internet." 13 (web)

This simplistic and somewhat nebulous definition was expanded during a more recent interview with Dodge:

"A WebQuest is built around an engaging and doable task that elicits higher order thinking of some kind. It's about doing something with information. The thinking can be creative or critical, and involve problem solving, judgment, analysis, or synthesis. The task has to be more than simply answering questions or regurgitating what's on the screen. Ideally, the task is a scaled down version of something that adults do on the job, outside school walls"14:2.

March ${ }^{15}$ worked closely with Dodge in developing the process and attributes of WebQuests, as well as the educational theory supporting the use of this teaching strategy. The constructivist and technology-enhanced approach to learning formed the foundation of the attributes required to design high quality WebQuests ${ }^{15,16}$.

The cornerstone of a well-designed WebQuest is the nature of the overall activity and tasks. The tasks should not merely require the student to present the information sourced from the internet, but rather apply it to a problem, challenge or skill ${ }^{16,17}$. The task stimulates the student's critical thinking, approach to problem-solving and judgement, and action in the task context is required ${ }^{14,15,17}$. Consequently, WebQuests are deemed to motivate students through presenting an authentic real-world challenge ${ }^{16-18}$. Aina and Sofowora ${ }^{18}$ surveyed 90 students to see whether they found the WebQuest to be beneficial to their learning, resulting in $49.1 \%$ strongly agreeing and $23.6 \%$ somewhat agreeing with the statement. Students reported that the nature of the WebQuest helped them concentrate on the learning activities, thus improving knowledge retention ${ }^{18}$.

The primary justification for selecting the WebQuest as the mode of delivery is that it is said to drive the intrinsic motivation of the student to participate in the learning process as it stimulates interest in the content and enhances enjoyment of the challenge that the WebQuest presents ${ }^{19}$. Kobylinski ${ }^{20}$ and Unal et al. ${ }^{17} \mathrm{em}-$ phasised that the design of the WebQuest plays an important role as it can impact the students' enjoyment and thus motivation to participate. In the Kobylinski ${ }^{20}$ study, the WebQuest was deemed to be simplistic and not modern, impacting the students' interest in participating. Kobylinski ${ }^{20}$ surveyed the student experience of a WebQuest designed to develop the English writing skills of first year students, and found that the students perceived it to be ineffective and less motivating than their self-directed research into the topic. He however acknowledged limitations in the rudimentary design, restrictive format, and the cumbersome tasks involved in this particular WebQuest. This raises the issue of the level of challenge present in the WebQuest, as establishing the just-right challenge or degree of difficulty of the learning tasks is a key driver of students' internal motivation ${ }^{21}$. Therefore, in order to investigate the impact of using a WebQuest of the students' intrinsic motivation, one can consider the student experiences in terms of enjoyment, finding the process interesting and how difficult the WebQuest was ${ }^{19-21}$.

While WebQuests are popular in secondary school education $^{22,23}$ and undergraduate teacher training ${ }^{24,25}$, there is a paucity of investigation into the use of WebQuests in health professionals' education, which further seems confined to nursing education. Sanford et al. ${ }^{26}$ propose two detailed examples of WebQuests which could be used in the continued professional development of nurses, but give no evidence of having executed either example in practice. Drozd and O'Donoghue ${ }^{27}$ implemented a short-term WebQuest with I I undergraduate nursing students. Four students did not complete the WebQuest, either due to poor computer skills or late registration for the course. The seven students who completed the WebQuest were positive about the learning process, the novelty and their knowledge gain. It was however emphasised that WebQuests should be launched face-to-face to ensure student understanding of and access to technology, and that direct alignment to the curriculum would make it more relevant ${ }^{27}$. In an era in which $\mathrm{BL}$ is prominent in higher education, it is surprising that health professionals' education is relatively oblivious to this tool.

WebQuests can be categorised as short-term or long-term, depending on the duration and complexity of the WebQuest ${ }^{13,17}$. Short-term WebQuests, as applied in this study, can be completed in a few sessions, focusing more on knowledge gain and understanding than on higher order application ${ }^{13,17}$. First-year students during the orientation sessions were frustrated at the varying pace of the stepby-step, face-to-face process where some students were slower and required more assistance due to poorer digital literacy and others were ahead and had to wait. This demotivated students at both ends of the spectrum. The pace of the step-by-step, face-to-face process was difficult for the presenters to manage (especially with larger classes) despite the involvement of support facilitators. The WebQuest was proposed as an option to alleviate such tensions, but it was important to understand the digital literacy of the students as they entered higher education and to determine whether the WebQuest as a tool was beneficial to learning and stimulated the students' internal motivation to participate through the self-paced nature and 'gamification' process ${ }^{18,19}$.

The study asks two research questions: I) Are the first-year students entering therapeutic sciences degree courses adequately prepared and do they have adequate access to meet the blended learning demands of their curriculum (digital literacy)? 2) Is a WebQuest a tool that improves students' motivation to participate in the learning process and do they perceive it to be beneficial to learning?

\section{METHOD}

The objectives of the study were to investigate:

* The students' personal computing access and perceived digital literacy on entrance to the first year of study.

* Their experiences of the WebQuest in terms of perceived benefit to learning

* The degree to which the WebQuest stimulated the students' intrinsic motivation through their perceived enjoyment, whether the WebQuest made learning interesting, and the degree of difficulty of the WebQuest. 
This study used a cross-sectional, descriptive quantitative survey design to evaluate the use of the WebQuest to orientate the first-year occupational therapy and physiotherapy students to the University's online resources. Ethical clearance was obtained from the institution's human research ethics committee (certificate MI4I I68), and all occupational therapy and physiotherapy students who engaged with the WebQuest were asked to participate in the study. Informed consent was electronically captured for the survey results to be used for research purposes after verbal explanation of the purpose of the study during the WebQuest introduction session.

\section{Participants}

The population of this study are the first-year occupational therapy and physiotherapy students from three consecutive years. This is a public funded University and as such students are admitted in accordance with an admissions policy which promotes transformation. Sixty percent of students are selected from top-achieving students at rural schools, low or no-fee paying schools or top-achieving African and coloured students ${ }^{28}$. Between 60 and 70 students are admitted for each of these degrees each year. The student body in these two degrees are predominantly female although there is a greater proportion of male students in the Physiotherapy classes. Six groups of students participated in the WebQuest over three consecutive academic years:

* 2015 first-year Occupational Therapy group: enrolment of 68 students $\left(\mathrm{OT}_{\mathrm{yl}}\right)$

* 2015 first-year Physiotherapy group: enrolment of 6 I students (PT $)$

* 2016 first-year Occupational Therapy group: enrolment of 65 students $\left(\mathrm{OT}_{\mathrm{y} 2}\right)$

* 2016 first-year Physiotherapy group: enrolment of 55 students $\left(\mathrm{PT}_{\mathrm{y} 2}\right.$ )

* 2017 first-year Occupational Therapy group: enrolment of 70 students $\left(\mathrm{OT}_{\mathrm{y} 3}\right)$

* 2017 first-year Physiotherapy group: enrolment of 64 students $\left(\mathrm{PT}_{\mathrm{y} 3}\right)$

\section{Intervention}

At the start of the academic year a two-hour workshop is scheduled to introduce the first-year students to the VLE and other university online resources. A WebQuest was designed using a 'Sherlock

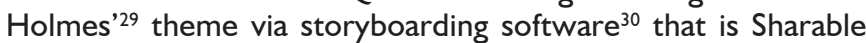
Content Object Reference Model (SCORM) compliant ${ }^{3 !}$. The first and second authors designed the tasks and with the assistance of a graphic designer, compiled the WebQuest from concept to an exportable storyboard over a five-week period. The SCORM file was then imported into a test class on the VLE, and was tested together with the supporting documents and assignments to en-

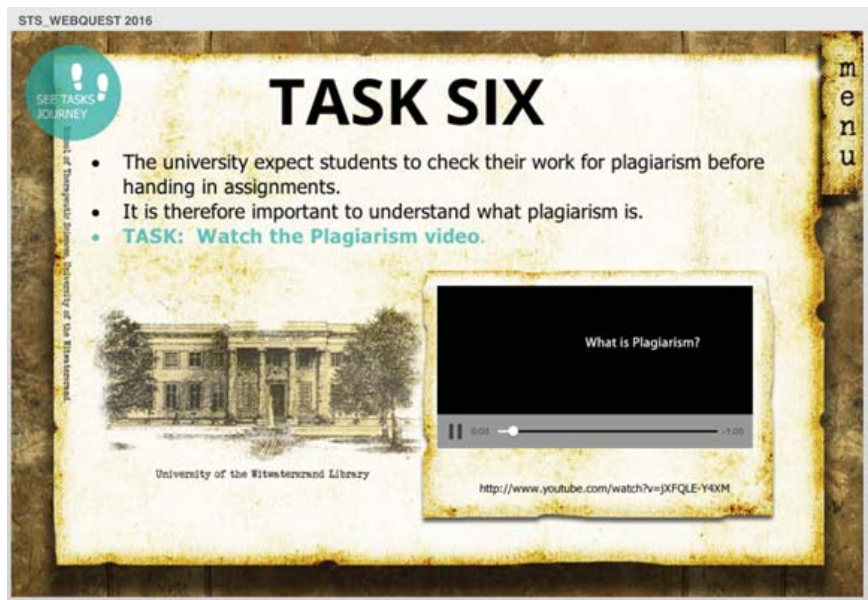

Figure I: Screenshot of the WebQuest task six (plagiarism video) sure the flow and test all hyperlinks. The WebQuest was imported into the pharmacy first-year class for piloting. The 94 pharmacy students completed the WebQuest one week prior to the OT and $\mathrm{PT}_{\mathrm{yl}}$. The WebQuest remained unchanged between the pilot and the $\mathrm{OT}_{\mathrm{y} 1}$ and $\mathrm{PT}_{\mathrm{yl}}$.

This short-term WebQuest consisted of 12 tasks which included updating their VLE profile page, downloading and reading important documents such as the 'social-media policy', accessing the professional course 'Libguide' on the library portal, watching a video on plagiarism (Figure I), writing a paragraph about plagiarism and submitting it to the plagiarism detection online programme, and completing a word puzzle and a quiz. The WebQuest was designed to orientate students to the university's online resources and policies and to create understanding of academic issues around plagiarism.

The WebQuest was introduced to the students in a computer laboratory (Figure 2) by one presenter and three facilitators who collaborated on the design of the WebQuest. The introduction ensured that all students could access the VLE and open the WebQuest. It could be completed within the 2-hour workshop time in the computer laboratory, but students were given the option to leave and do it in their own time. They were free to work individually or in informal groups, but all students were required to complete the WebQuest within six-weeks, although no marks were associated with the activity.

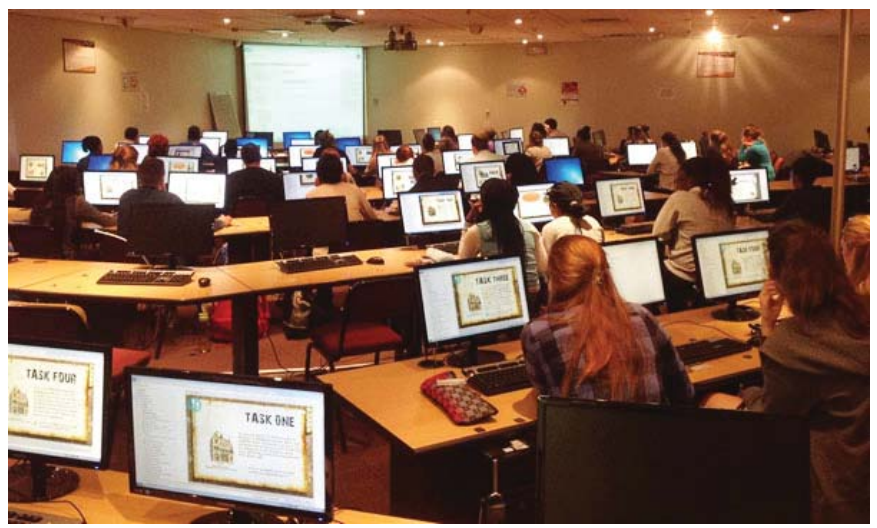

Figure 2: Students during the WebQuest in the computer laboratory

The students were introduced to the study during the WebQuest introduction, the purpose was explained and assurance given that participation in the study was voluntary with no consequence for non-participation. Students were assured that their responses would remain confidential and that the only identifying information would be the degree for which they were enrolled. An electronic informed consent was included as a link via an electronic form that allowed students to download a copy of their consent. This consent form was on a different platform to the survey.

\section{Extraneous variables}

While all effort was made to control for extraneous variables, the facilitators of the intervention noted that the $\mathrm{OT}_{\mathrm{y}^{2}}$ was in an unfamiliar computer venue which led to a delayed start to the session. Poor projection visibility in this venue created additional difficulty in following the introductory presentation. This caused a general level of frustration and apathy among the $\mathrm{OT}_{\mathrm{y2}}$ students.

\section{Survey}

A purpose-designed survey instrument, informed by the literature on WebQuest research ${ }^{18,19}$, was created using REDCap ${ }^{32}$, which securely captures and allows management of the data via a webbased interface. The survey consisted of:

* the student number was requested as an identifier (optional) * two demographic questions to verify cohort allocation (registered degree and year of study); 
* two multi-option categorical questions related to the students' personal computing environment (type of device and mode of internet access);

* students' rating of their electronic media proficiency on an ordinal scale from I (very poor) to I0 (excellent);

* four nominal scale questions to investigate their experience of the WebQuest, namely: benefit to learning, made learning process interesting, enjoyment of the WebQuest and the level of difficulty of the WebQuest. The questions and scales were based on other surveys from the WebQuest literature ${ }^{12,18,20 \text {. }}$

* two optional, short answer questions that were included to support responses.

The survey was peer-reviewed by four lecturers with experience in blended learning and survey-based research for content validity and structure. The first-year pharmacy students from 2015 participated in the WebQuest during their orientation week and completed the survey as a pilot. It was apparent that there were duplicate responses, thus a field to enter a student number was included. It was further apparent that there were fewer consent responses from the pharmacy students than survey responses. The student number was thus also included in the informed consent in order to cross-reference surveys to consent given. The survey was shortened by removing two questions which were covered by the open-ended questions. The survey was the final task of the WebQuest, but students were given the option to 'skip' the task should they not consent to participate in the study.

A neutral research assistant cleaned the data in that any survey responses without consent or that were duplicate responses were removed from the data and the student numbers removed prior to the researchers analysing the data. The data from the six student groups were descriptively analysed using non-parametric statistics. Categorical data were analysed for significance using the Freeman-Halton extension of the Fisher exact probability test $(\mathrm{FE})$ or the Chi-square test $\left(\chi^{2}\right)$ as appropriate, based on category frequency. The $p$-value was analysed using the Chi-Square test $\left(\chi^{2}\right)$ if over $80 \%$ of categories had a frequency $<5$, and the Fisher Exact (FE) when less than $80 \%$ was evident. Ordinal data were analysed using the Kruskal-Wallis $\mathrm{k}=3 \mathrm{Test}^{33,34}$. A p-value $\leq 0.05$ was considered significant.

The short response data were open coded and analysed for patterns of frequently cited experiences using MaxQDA version I 2. I.4 software ${ }^{35}$. Frequently cited codes for each question were reported on.

\section{RESULTS}

The WebQuest was completed by 383 first year Occupational Therapy and Physiotherapy students over a three-year period (20I5-20I7), of which $65.3 \%$ completed the survey. The response rates per group were $(\mathrm{n}(\%))$ : OT $57(83.8 \%)$; $\mathrm{PT}_{\mathrm{yl}} 38(62.3 \%)$; $\mathrm{OT}_{y 2} 45(69.2 \%) ; \mathrm{PT}_{y 2} 40(72.7 \%) ; \mathrm{OT}_{y 3} 47(67.1 \%)$ and the lowest response rate $\mathrm{PT}_{\mathrm{y} 3} 23(35.9 \%)$.

The students' preferred device for accessing electronic media and their connectivity preference at the start of their undergraduate career is reflected in Table $I$ (this page) and Table II (page 7) respectively. There were no significant differences in computing preferences when compared year on year within each profession, and between profession groups per year, except when comparing the preferred computing devices of the third year $\mathrm{OT}_{y 3}: \mathrm{PT}_{y^{3}}(p=0.023)$ where the OT had significantly higher preference for personal computers/ laptops. This indicates that the groups are comparable in terms of technology preferences.

The majority of the students preferred using their personal computer/laptop (64.8\%) and had access to home based internet $(66.8 \%)$. Of note is the small number of students $(<1 \%)$ who have no access to a device or the internet.

In rating their computer or electronic media proficiency (Table III (page 7) there was no significant difference between the groups, with a total mean rating of $\mathrm{m}=7.6 \mathrm{I}$ on a 10 -point scale, with a mere $19(7.6 \%)$ students rating their proficiency at five or less over the three years of the study.

The students' perception of benefit to learning (Table IV on page 7) showed that more than half of the students $(56.2 \%)$ rated the benefit to learning as good.

The students' perception of how difficult they felt the WebQuest was (Table V page 8) is important to establishing the impact it may have on the student participation. Two-thirds of the students perceived the level of difficulty of the WebQuest to be 'just right' (65.2\%).

In order to investigate the WebQuest's role in the intrinsic motivation to learn, the students' perception of enjoyment of the WebQuest and whether it made the learning process more interesting was surveyed (Table VI pge 8). The students were relatively evenly distributed between being undecided $(39.4 \%)$ and enjoying $(44.6 \%)$ the WebQuest, with the Occupational Therapy groups showing significantly different profiles of enjoyment from one another. Most students (62.9\%) considered that the learning process was made more interesting through the WebQuest.

Table I: Students' preferred computing devices for accessing electronic media

\begin{tabular}{|c|c|c|c|c|c|c|c|c|}
\hline & \multirow{2}{*}{$\begin{array}{c}\begin{array}{c}\text { Personal } \\
\text { computer/ } \\
\text { laptop }\end{array} \\
\mathrm{n}(\%)\end{array}$} & \multirow{2}{*}{$\begin{array}{c}\text { Computer at } \\
\text { library/public } \\
\text { computer }\end{array}$} & \multirow{2}{*}{$\begin{array}{c}\begin{array}{c}\text { Tablet } \\
\text { computing } \\
\text { device }\end{array} \\
\mathrm{n}(\%)\end{array}$} & \multirow{2}{*}{$\begin{array}{c}\begin{array}{c}\text { Mobile } \\
\text { device }\end{array} \\
n(\%)\end{array}$} & \multirow{2}{*}{$\begin{array}{c}\text { More } \\
\text { than one } \\
\mathrm{n}(\%)\end{array}$} & \multirow{2}{*}{$\begin{array}{l}\text { None } \\
\mathrm{n}(\%)\end{array}$} & \multicolumn{2}{|c|}{ Year on Year comparison } \\
\hline & & & & & & & & $\begin{array}{c}\chi^{2}(\mathrm{p} \text {-value }) / \\
\text { FE p-value }\end{array}$ \\
\hline $\mathrm{OT}_{\mathrm{yl}} \mathrm{n}=57$ & $39(68.4)$ & $10(17.5)$ & $10(17.5)$ & $23(40.4)$ & $16(36.8)$ & $0(0.0)$ & $\mathrm{OT}_{\text {yl:y2 }}$ & $0.585(1.9)$ \\
\hline $\mathrm{OT}_{\mathrm{y}^{2}} \mathrm{n}=45$ & $33(73.3)$ & $5(11.1)$ & $4(8.9)$ & $17(37.8)$ & $9(20.0)$ & $0(0.0)$ & $\mathrm{OT}_{y 2: y^{3}}$ & 0.940 \\
\hline $\mathrm{OT}_{y^{3}} \mathrm{n}=47$ & $30(63.8)$ & $3(6.4)$ & $4(8.5)$ & $17(36.2)$ & $6(12.8)$ & $0(0.0)$ & $\mathrm{OT}_{y 1: y^{3}}$ & $0.428(2.8)$ \\
\hline $\begin{array}{l}\text { TOTAL } \\
\mathrm{N}_{\mathrm{OT}}=149\end{array}$ & $102(68.5)$ & $18(12.1)$ & $18(12.1)$ & $57(38.3)$ & $31(20.8)$ & $0(0.0)$ & & \\
\hline $\mathrm{PT}_{y \mid} \mathrm{n}=38$ & $26(68.4)$ & $9(23.7)$ & $10(26.3)$ & $16(42.1)$ & $13(34.2)$ & $\mathrm{I}(2.4)$ & $\mathrm{PT}_{y 1: y 2}$ & $0.196(4.7)$ \\
\hline $\mathrm{PT}_{\mathrm{y}^{2}} \mathrm{n}=40$ & $27(67.5)$ & $7(17.5)$ & $2(5.0)$ & $14(35.0)$ & $7(17.5)$ & $0(0.0)$ & $\mathrm{PT}_{y 2: y^{3}}$ & 0.075 \\
\hline $\mathrm{PT}_{y^{3}} \mathrm{n}=23$ & $7(30.4)$ & $6(26.1)$ & $4(17.4)$ & $9(39.1)$ & $3(13.0)$ & $0(0.0)$ & $\mathrm{PT}_{y 1: y^{3}}$ & 0.483 \\
\hline $\begin{array}{l}\text { TOTAL } \\
N_{P T}=101\end{array}$ & $60(59.4)$ & $21(20.8)$ & $16(15.8)$ & $39(38.6)$ & $23(22.8)$ & $\mathrm{I}(\mathrm{I} .0)$ & & \\
\hline $\begin{array}{l}\text { TOTAL OT+PT } \\
\mathrm{N}_{\mathrm{all}}=250\end{array}$ & $162(64.8)$ & $39(15.6)$ & $34(13.6)$ & $96(38.4)$ & $54(21.6)$ & I $(0.4)$ & & \\
\hline
\end{tabular}


Table II: Students' preferred modality for access to the internet

\begin{tabular}{|l|c|c|c|c|c|c|c|c|}
\hline & $\begin{array}{c}\text { Internet } \\
\text { at home }\end{array}$ & $\begin{array}{c}\text { Internet } \\
\text { at } \\
\text { residence }\end{array}$ & $\begin{array}{c}\text { Internet } \\
\text { on campus }\end{array}$ & $\begin{array}{c}\text { Mobile } \\
\text { data }\end{array}$ & $\begin{array}{c}\text { More } \\
\text { than one }\end{array}$ & \multicolumn{2}{|c|}{ None } & \multicolumn{2}{|c|}{ Year on Year comparison } \\
\cline { 2 - 8 } & $\mathrm{n}(\%)$ & $\mathrm{n}(\%)$ & $\mathrm{n}(\%)$ & $\mathrm{n}(\%)$ & $\mathrm{n}(\%)$ & $\mathrm{n}(\%)$ & $\mathrm{P}$-value $\left(\chi^{2}\right) / \mathrm{FE}$ \\
$\mathrm{P}-\mathrm{value}$
\end{tabular}

Table III: Students' perceived computer/electronic media competence

\begin{tabular}{|c|c|c|c|c|}
\hline & Range & Mode & $\begin{array}{l}\text { Mean } \\
\text { (SD) }\end{array}$ & $\begin{array}{c}\text { Kruskal-Wallis Test } \\
\mathbf{k}=\mathbf{3} \\
\mathbf{p} \text {-value }\end{array}$ \\
\hline $\mathrm{OT}_{y \mid} n=57$ & $3-10$ & 8 & $7.95(I .4 I)$ & \\
\hline $\mathrm{OT}_{\mathrm{y} 2} \mathrm{n}=45$ & $1-10$ & 7 & $7.24(\mathrm{I} .7 \mathrm{I})$ & 0.123 \\
\hline $\mathrm{OT}_{y 3} \mathrm{n}=47$ & $5-10$ & 8 & $7.75(1.47)$ & \\
\hline $\mathrm{PT}_{\mathrm{y} 1} \mathrm{n}=38$ & $4-10$ & 8 & $7.42(1.4 I)$ & \\
\hline $\mathrm{PT}_{y 2} \mathrm{n}=40$ & $5-10$ & 8 & $7.73(1.45)$ & 0.403 \\
\hline $\mathrm{PT}_{y 3} \mathrm{n}=23$ & $4-9$ & 8 & $7.30(1.26)$ & \\
\hline
\end{tabular}

Table IV: Students' perceptions of the WebQuest as being beneficial to learning

\begin{tabular}{|c|c|c|c|c|c|c|}
\hline & \multirow{2}{*}{$\begin{array}{l}\text { Poor } \\
\mathrm{n}(\%)\end{array}$} & \multirow{2}{*}{$\begin{array}{c}\text { Satisfactory } \\
\mathrm{n}(\%)\end{array}$} & \multirow{2}{*}{$\begin{array}{l}\text { Good } \\
\mathrm{n}(\%)\end{array}$} & \multirow{2}{*}{$\begin{array}{c}\text { Excellent } \\
\mathrm{n}(\%)\end{array}$} & \multicolumn{2}{|c|}{ Year on Year comparison } \\
\hline & & & & & & $\begin{array}{c}\text { P-value }\left(\mathrm{X}^{2}\right) / \\
\text { FE p-value }\end{array}$ \\
\hline $\mathrm{OT}_{y \mid} \mathrm{n}=57$ & $0(0.0)$ & $9(15.8)$ & $36(63.2)$ & $12(21.1)$ & $\mathrm{OT}_{y 1: y 2}$ & $0.043 *$ \\
\hline $\mathrm{OT}_{\mathrm{y} 2} \mathrm{n}=44$ & $2(2.2)$ & $14(3 \mid .8)$ & $24(54.5)$ & $4(9.1)$ & $\mathrm{OT}_{y 2: y_{3}}$ & 0.926 \\
\hline $\mathrm{OT}_{\mathrm{y3}} \mathrm{n}=47$ & $3(6.4)$ & $15(31.9)$ & $23(48.9)$ & $6(12.8)$ & $\mathrm{OT}_{y 1: y 3}$ & $0.035 *$ \\
\hline $\begin{array}{l}\text { TOTAL } \\
\mathrm{N}_{\mathrm{OT}}=148\end{array}$ & $5(3.4)$ & $38(25.7)$ & $83(56.1)$ & $22(14.9)$ & & \\
\hline $\mathrm{PT}_{y 1} \mathrm{n}=38$ & $0(0.0)$ & $14(36.8)$ & $19(50.0)$ & $5(13.2)$ & $\mathrm{PT}_{\mathrm{yl}: \mathrm{y}^{2}}$ & 0.172 \\
\hline $\mathrm{PT}_{y 2} \mathrm{n}=40$ & $2(5.0)$ & $10(25.0)$ & $26(65.0)$ & $2(5.0)$ & $\mathrm{PT}_{y 2: y^{3}}$ & 0.112 \\
\hline $\mathrm{PT}_{y 3} \mathrm{n}=23$ & I (4.3) & $4(17.4)$ & $12(52.2)$ & $6(26.1)$ & $\mathrm{PT}_{\mathrm{yl:y3}}$ & 0.156 \\
\hline $\begin{array}{l}\text { TOTAL } \\
N_{\mathrm{PT}}=101\end{array}$ & $3(3.0)$ & $28(27.7)$ & $57(56.4)$ & $13(12.9)$ & & \\
\hline $\begin{array}{l}\text { TOTAL OT +P } \\
\mathrm{N}_{\mathrm{all}}=249\end{array}$ & $8(3.2)$ & $66(26.5)$ & $140(56.2)$ & $35(14.1)$ & & \\
\hline
\end{tabular}

Across all four nominal scale questions there was no difference in the results of the Physiotherapy groups. The $\mathrm{OT}_{\mathrm{y} 2}$ and $\mathrm{OT}_{\mathrm{y3}}$ were similar, but significantly different from OT for benefit to learning, difficulty and making the learning process more interesting. The Occupational Therapy students' enjoyment of the WebQuest appears to wane each year with a significant difference noted between each year.

The two optional, short open-ended questions explored aspects the students' 'liked' versus 'disliked' aspects of the WebQuest (2I 7 responses). Students across the groups commented that this was a novel way to learn $(n=22)$, with it being like a game $(n=17)$, which made it fun $(n=7 I)$. They liked that it was self-paced learning, that taught them relevant and useful information that they would be able to apply in their course $(\mathrm{n}=98)$.

People are more positive about learning when they see the learning process as a game and I think [the] WebQuest was successful in allowing people to have fun while still learning valuable information. (Student I40 $\mathrm{PT}_{\mathrm{yl}}$ )

Instead of the controversial lecturer standing in front of the class type 
Table V: Students' perceptions of the level of difficulty of WebQuest

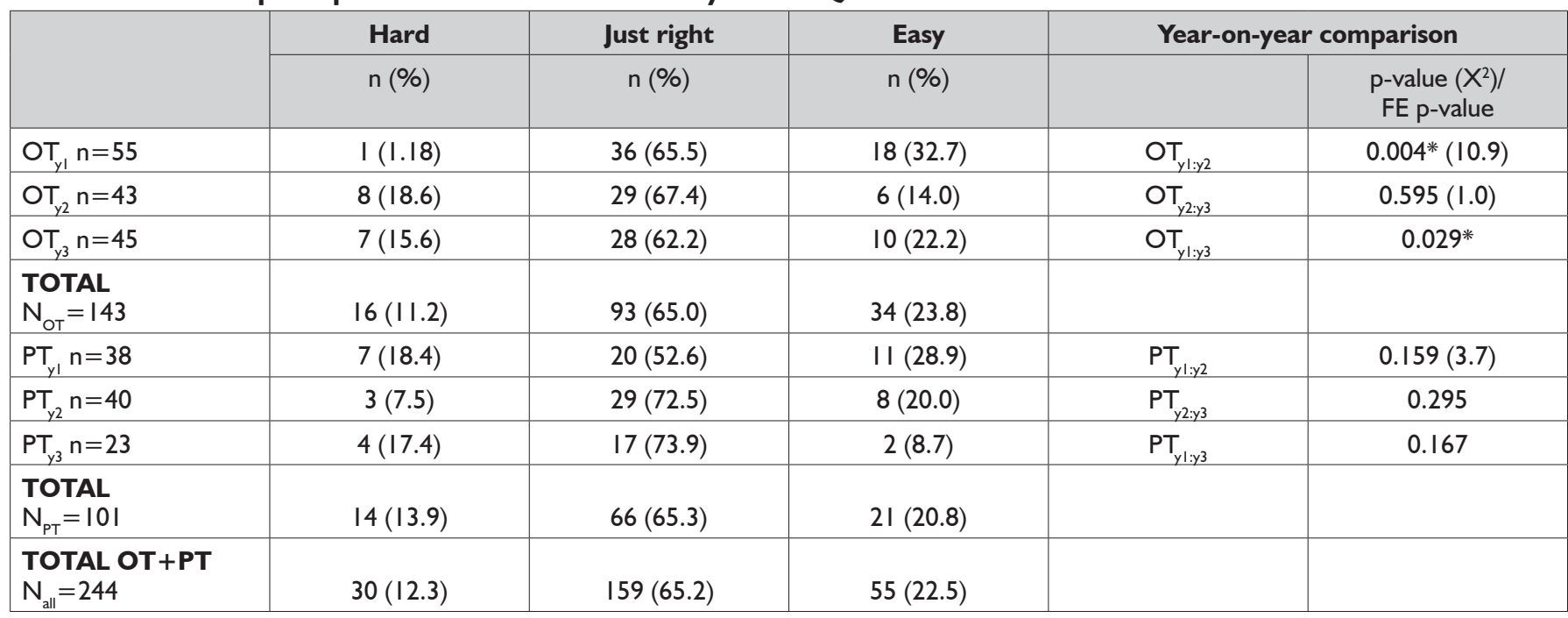

Table VI: Students' perceptions of the WebQuest for intrinsic motivation

\begin{tabular}{|c|c|c|c|c|c|}
\hline \multicolumn{4}{|c|}{ Enjoyed the learning process } & & \\
\hline & no & undecided & yes & \multicolumn{2}{|c|}{ Year-on-year comparison } \\
\hline & n (\%) & $\mathrm{n}(\%)$ & $n(\%)$ & & $\begin{array}{l}\text { p-value }\left(X^{2}\right) / \\
\text { FE p-value }\end{array}$ \\
\hline $\mathrm{OT}_{y 1} \mathrm{n}=57$ & $2(3.5)$ & $18(31.6)$ & $37(64.9)$ & $\mathrm{OT}_{\mathrm{y1}: \mathrm{y} 2}$ & $0.000 *$ \\
\hline $\mathrm{OT}_{\mathrm{y} 2} \mathrm{n}=45$ & $5(I I . I)$ & $29(64.4)$ & II (24.4) & $\mathrm{OT}_{y 2: y^{3}}$ & $0.042 *(6.3)$ \\
\hline $\mathrm{OT}_{\mathrm{y} 3} \mathrm{n}=47$ & $10(21.3)$ & $18(38.3)$ & $19(40.2)$ & $\mathrm{OT}_{y 1: y 3}$ & $0.006 *(10.3)$ \\
\hline $\begin{array}{l}\text { TOTAL } \\
\mathrm{N}_{\text {OT }}=149\end{array}$ & $17(11.4)$ & $65(43.6)$ & $67(45.0)$ & & \\
\hline $\mathrm{PT}_{y 1} \mathrm{n}=37$ & $6(16.2)$ & $14(37.8)$ & $17(45.9)$ & $\mathrm{PT}_{\mathrm{yl}: \mathrm{y}_{2}}$ & $0.160(3.7)$ \\
\hline $\mathrm{PT}_{\mathrm{y} 2} \mathrm{n}=40$ & $14(35.0)$ & $13(32.5)$ & $13(32.5)$ & $\mathrm{PT}_{y 2: y^{3}}$ & $0.062(5.6)$ \\
\hline $\mathrm{PT}_{\mathrm{y} 3} \mathrm{n}=23$ & $3(13.0)$ & $6(26.1)$ & $14(60.9)$ & $\mathrm{PT}_{\mathrm{yl:y3}}$ & $0.525(1.3)$ \\
\hline $\begin{array}{l}\text { TOTAL } \\
N_{\mathrm{PT}}=100\end{array}$ & $23(23.0)$ & $33(33.0)$ & $44(44.0)$ & & \\
\hline $\begin{array}{l}\text { TOTAL OT+PT } \\
\mathrm{N}_{\mathrm{all}}=249\end{array}$ & $40(16.1)$ & $98(39.4)$ & III (44.6) & & \\
\hline \multicolumn{6}{|c|}{ Makes the learning process more interesting } \\
\hline & no & undecided & yes & \multicolumn{2}{|c|}{ Year-on-year comparison } \\
\hline & n (\%) & $\mathrm{n}(\%)$ & n (\%) & & $\begin{array}{c}\text { P-value }\left(\mathrm{X}^{2}\right) / \\
\text { FE p-value }\end{array}$ \\
\hline $\mathrm{OT}_{y \mid} n=56$ & $0(0.0)$ & $10(17.9)$ & $46(82.1)$ & $\mathrm{OT}_{\mathrm{yl}: \mathrm{y2}}$ & $0.000 *$ \\
\hline $\mathrm{OT}_{\mathrm{y} 2} \mathrm{n}=43$ & $5(11.6)$ & $18(41.9)$ & $20(46.5)$ & $\mathrm{OT}_{y 2: y^{3}}$ & 0.781 \\
\hline $\mathrm{OT}_{\mathrm{y} 3} \mathrm{n}=46$ & $4(8.7)$ & $17(37.0)$ & $25(54.3)$ & $\mathrm{OT}_{y 1: y 3}$ & $0.003^{*}$ \\
\hline $\begin{array}{l}\text { TOTAL } \\
\mathrm{N}_{\mathrm{OT}}=145\end{array}$ & $9(6.2)$ & $45(31.0)$ & $91(62.8)$ & & \\
\hline $\mathrm{PT}_{\mathrm{yl}} \mathrm{n}=38$ & $2(5.3)$ & $10(26.3)$ & $26(68.4)$ & $\mathrm{PT}_{\mathrm{yl}: \mathrm{y}^{2}}$ & $0.150(3.8)$ \\
\hline $\mathrm{PT}_{y 2} \mathrm{n}=40$ & $8(20.0)$ & $9(22.5)$ & $23(57.5)$ & $\mathrm{PT}_{y 2: y^{3}}$ & 0.931 \\
\hline $\mathrm{PT}_{y 3} \mathrm{n}=22$ & $3(13.6)$ & $5(22.7)$ & $14(63.6)$ & $\mathrm{PT}_{\mathrm{yl}: \mathrm{y}^{3}}$ & 0.527 \\
\hline $\begin{array}{l}\text { TOTAL } \\
N_{P T}=100\end{array}$ & $13(13.0)$ & $24(24.0)$ & $63(63.0)$ & & \\
\hline $\begin{array}{l}\text { TOTAL OT+PT } \\
N_{\mathrm{all}}=245\end{array}$ & $22(9.0)$ & $69(28.2)$ & $154(62.9)$ & & \\
\hline
\end{tabular}


of learning it actually was a total contrast of what learning is and that made it very intriguing. (Student $262 \mathrm{OT}_{\mathrm{y} 3}$ )

I) It was self-learning versus just being lectured. 2) Involved a lot of participation from my part. 3) I was not spoon fed which made the learning more meaningful. (Student $145 \mathrm{PT}_{\mathrm{y} 2}$ )

Students reported that the WebQuest instructions were confusing or unclear $(n=16)$, yet 14 students reported the instructions were clear. Students felt it was too time consuming $(n=53)$ and that they did not enjoy reading the long policy documents $(n=29)$. There were reports of technical difficulties $(n=42)$ particularly with the $\mathrm{OT}_{\mathrm{y2}}$ and $\mathrm{OT}_{\mathrm{y3}}$ cohorts: internet connectivity; the browser freezing; students finding it difficult to navigate between the tabs; and the WebQuest not saving their progress.

It was more the technological difficulties that gave problems such as internet connection. (Student $7 \mid \mathrm{OT}_{\mathrm{y} 2}$ )

It took up quite a bit of time simply because internet was slow and some features did not work on some devices. It was a lot of work just to go through things which were rather easy to figure out anyway. Although innovative and fun, when it started to waste time, the originality turned into an irritation. (Student $274 \mathrm{OT}_{\mathrm{y} 3}$ )

\section{DISCUSSION}

Blended Learning $(B L)$ in South African universities is challenged by concerns that some students enter higher education with poor digital literacy skills due to unevenly distributed access to technology resources during their high school career ${ }^{2}$. Of interest in the present study and consistent with other research, is the high percentage who choose to use a personal computer/laptop and access electronic media via home-based internet, as well as the number of students who have more than one computing device and more than one modality of internet access ${ }^{\prime \prime}$. Surprisingly, less than half the students indicated the use of a mobile device and mobile data as a preference. This does not imply that they do not have mobile devices, merely that they prefer other modalities for accessing electronic media, which may be a reflection on the relatively high cost of mobile data in South Africa ${ }^{36}$. It therefore supports the need for access to stable university-funded bandwidth. Despite common concerns about the digital literacy of first year students ${ }^{1,2}$, the study groups were confident about their electronic media proficiency, which primes them for blended learning. Drozd and O'Donoghue ${ }^{27}$ highlighted that the success of a WebQuest may be impacted by the students' access to computers and digital literacy skills, however, in this study, less than I\% of students were limited by access, and a small percentage of students felt that their electronic media proficiency was poor/average (7.6\%). The readiness of these students suggests that WebQuests are a viable BL strategy in this population, but the difficulty of the WebQuest may be a factor. Overall, the students felt that the level of difficulty of the WebQuest was 'just right' (65.2\%).

Similar to Aina and Sofowora ${ }^{18}$, the Occupational Therapy and Physiotherapy students perceived the WebQuest as beneficial to their learning ( $70.3 \%$ rated it as 'good' or 'excellent'). For a WebQuest to be successful, it needs to be authentic and real-world ${ }^{15}$ - which is validated in the student comments that the content of the WebQuest was meaningful and valuable and $62.9 \%$ felt the WebQuest made the learning process more interesting. Studies of the benefits of using WebQuests seldom consider the students' perceived enjoyment as a construct to investigate, rather adding minor anecdotal comment on observed indications that students have enjoyed $i^{19,27}$. There were very few negative responses, but students were divided between being undecided (39.4\%) and being positive $(44.6 \%)$ concerning their enjoyment of the WebQuest.

The notable finding in this study is the results of the three Occupational Therapy student groups, which supports the relationship between perceived difficulty, enjoyment of the WebQuest, and the learning process being interesting as an indication of intrinsic motivation to participate, and in turn, in the perceived benefit of the WebQuest to learning. The $\mathrm{OT}_{\mathrm{yl}}(91.2 \%)$ felt that the difficulty of the WebQuest was just right and easy, significantly more than $\mathrm{OT}_{y 2}(81.4 \%)$ and $\mathrm{OT}_{y 3}(84.4 \%)$. This appears to associate with significantly higher enjoyment of the WebQuest by OT $(64.9 \%)$ and $82.1 \%$ felt that the WebQuest made the learning process more interesting. The impact on their perception of the WebQuest as being beneficial to learning is evident in that $84.3 \%$ of $\mathrm{OT}_{\mathrm{yl}}$ felt it was good and excellent as opposed to only $63.6 \%$ of $\mathrm{OT}_{y_{2}}$ and $61.7 \%$ of $\mathrm{OT}_{y 3}$. The frustrations expressed by the students, particularly the technical difficulties experienced by $\mathrm{OT}_{\mathrm{y} 2}$ and $\mathrm{OT}_{\mathrm{y} 3}$ cohorts, and that all cohorts felt that the WebQuest was too long with too much reading, possibly accounts for the shift in enjoyment, as was described in the quote by Student $274 \mathrm{OT}_{y 3}$ above. It is important to recognise that enjoyment is subjective and may not be directly correlated to students' finding the process interesting or learning from the experience.

The students' primary frustration was that some of the policy and guideline documents they had to download were too readingintensive. This possibly relates to the point at which required reading skills and comprehension 'ratchet up' between secondary and tertiary education, and the diversity of academic preparedness of our students, many of whom have experienced socio-cultural inequality ${ }^{2}$. They showed reluctance to engage with large documents, despite hyperlinked navigation of the document contents. These documents represent the prescribed readings that would be required throughout their undergraduate careers. This reflects the poor online/electronic reading literacy compared to paper-based reading literacy, and the impact of navigation and information seeking skills on reading ${ }^{10}$. Selection of prescribed readings should therefore take readability into account, and University documents could be designed to be more user-friendly. The online/electronic reading literacy of the students was not the focus of the study but has impacted the students' enjoyment of the WebQuest and indicates a possible area of concern in their academic readiness. This suggests that a WebQuest - focusing on information literacy and academic writing - could be developed for students to participate in should they feel they need it.

\section{Limitations of the Study}

The limitations that were evident during this study were:

* The computer laboratory venue was not consistent between the groups which implies that the computers the students used to access the WebQuests may have had inconsistent processing power and internet bandwidth speeds.

* The study was not designed to compare the use of a WebQuest to a control teaching method, such as the traditional step-bystep workshop, as the survey questions relating to the student experience would not be applicable to both contexts, leaving little to compare.

* The study is confined to a single university setting. While the study was conducted over three years with relatively consistent findings, replicability is limited due to the WebQuest design being specific to the VLE and online resources available at this particular university. A similar WebQuest could however be modelled on the same tasks for use at other Universities.

\section{CONCLUSION}

A WebQuest was designed to introduce first year Occupational Therapy and Physiotherapy students to $\mathrm{BL}$ and online tools and resources available within the University. The students indicated higher than anticipated access to computing devices and off-campus internet access, and perceived their electronic media proficiency to be very good. There was evidence of a relationship between the degree of difficulty of the WebQuest to influence the intrinsic motivation of the students, and in turn impacting their perceived benefit of the WebQuest to their learning. Of concern was the students' reluctance to read lengthy documents possibly indicating that the online/electronic reading literacy of the students impacted 
their enjoyment of the WebQuest. Students found the WebQuest to be too long, indicating that revision of the tasks and scheduling appropriate time for completion should be explored. The WebQuest is considered to have achieved the desired skills and learning objectives, and the students experienced it as an interesting, creative and fun way to learn.

Considerations for the future within this context include: The WebQuest should be confined to a single laboratory session to combat the technical issues. Consideration should be given to reducing the overall length of the WebQuest and exploring design modifications which support ease of reading task instructions, while maintaining the learning objectives. A task on navigating large electronic documents to find pertinent information may be a valuable future addition. This study indicates that a dialogue should be opened with the University's central services involved in developing and publishing rules and guideline documents, regarding the readability and complexity of the documents they publish.

Further research into the relationship between students' perception of how difficult a WebQuest is and the impact it has on intrinsic motivation (as indicated by enjoyment and how it makes the learning process interesting) should be explored. While intrinsic motivation is viewed as improving student engagement with the content ${ }^{20}$, further investigation to whether there is increased benefit to learning and if this translates into improved digital literacy skills, is warranted.

Considerations for implementation of WebQuests in health professional education: Exposing students to a WebQuest early in their academic career provides lecturers with the opportunity to explore the use of WebQuests in their BL modules, and has been shown to improve the students' digital literacy ${ }^{12}$. Short-term WebQuests create a fun context to learn and explore real-world issues within the context of the curriculum. In designing a WebQuest for health professionals' education, ensure that it has a fixed duration (one to two weeks) to drive consistent participation. Consider the availability of electronic devices and allocate time in a computer laboratory if one suspects that students' access to the WebQuest content will be influenced by the need to pay for mobile data. Students are entering higher education with a high level of computer and electronic media proficiency, which is creating more opportunities to use BL activities such as WebQuests to design for 2 I $^{\text {st }}$ century learning.

\section{REFERENCES}

I. Papageorgiou E, Callaghan C. Resource scarcity and information technology: Issues and trends among first-year accounting students. South African Journal of Higher Education. 20 I4; 28(5): I575-I592.

2. Kajee L, Balfour R. Students' access to digital literacy at a south african university: Privilege and marginalisation. Southern African Linguistics \& Applied Language Studies. 20 I I; 29(2): I87-I96.

3. Snowball J, Mostert M. Introducing a learning management system in a large first year class: Impact on lecturers and students. South African Journal of Higher Education. 20I0; 24(5): 8I8-83I.

4. McDonald PL, Straker HO, Schlumpf KS, Plack MM. Learning partnership: Students and faculty learning together to facilitate reflection and higher order thinking in a blended course. Online Learning. 2014; 18(4)

5. Ocak MA, Topal AD. Blended learning in anatomy education: $A$ study investigating medical students' perceptions. EURASIA Journal of Mathematics, Science \& Technology Education. 20 I 5; I I (3): 647663.

6. Alghamdi A. Pedagogical implications of using discussion board to improve student learning in higher education. Higher Education Studies. 20I3; 3(5): 68-80.

7. Umek L, Aristovnik A, Tomaževic N, Keržic D. Analysis of selected aspects of students' performance and satisfaction in a moodle-based e-learning system environment. EURASIA Journal of Mathematics, Science \& Technology Education. 20 I5; I I (6): I495- I 505.

8. Mogus AM, Djurdjevic I, Suvak N. The impact of student activity in a virtual learning environment on their final mark. Active Learning in Higher Education. 2012; 13(3): 177-189.

9. Siemens G, Conole G. Special issue - connectivism: Design and delivery of social networked learning - editorial. International Review of Research in Open and Distance Learning. 20 I I I2(3): I- I.

10. Wu JY, Peng Y-C. The modality effect on reading literacy: Perspectives from students' online reading habits, cognitive and metacognitive strategies, and web navigation skills across regions. Interactive Learning Environments. 2016: I-I8.

II. Pak M. Developing academic technology skills with webquests. California English. 20I5; 2 I(I): II-I3.

12. Leung CB, Unal Z. Advantages and disadvantages of classroom instruction with webquests: Connecting literacy and technology. Journal of Reading Education. 2013; 38(2): 31-38.

13. Dodge B. "Some thoughts about webquests". 1995. <http://webquest.org/sdsu/about_webquests.html> (27 June 2016)

14. Starr L. Wire side chat: Bernie dodge on webquests. Interview with Dodge B. Education World. 2012.

15. March T. The learning power of webquests. Educational Leadership. 2003; 61 (4): 42-47.

16. Averkieva L, Chayka Y, Glushkov S. Web quest as a tool for increasing students' motivation and critical thinking development. Procedia Social and Behavioral Sciences. 2015; 206: 137-140.

17. Unal Z, Bodur Y, Unal A, Kovacic Z. A standardized rubric for evaluating webquest design: Reliability analysis of zunal webquest design rubric. Journal of Information Technology Education. 20I2; II: 169-183.

18. Aina SA, Sofowora AO. Perceived benefits and attitudes of student teachers to web-quest as a motivating, creative and inquiry-based learning tool in education. Higher Education Studies. 2013; 3(5): 29-35.

19. Kurt S. Webquests and web 2.0 screen design. Journal of Technology in Human Services. 2010; 28(3): 178-187.

20. Kobylinski C. Student feedback on the effectiveness of using a webquest for an integrative skills course in a korean university. Contemporary Issues in Education Research. 20I4; 7(I): 63-68.

21. Rodger S, Thomas Y, Greber C, Broadbridge J, Edwards A, Newton J, et al. Attributes of excellence in practice educators: The perspectives of australian occupational therapy students. Australian Occupational Therapy Journal. 20I4; 6I(3): I59-I67.

22. Kurt $\mathrm{S}$. Issues to consider in designing webquests: A literature review. Computers in the Schools. 2012; 29(3): 300-3I4.

23. Zheng R, Stucky B, McAlack M, Menchana M, Stoddart S. Webquest learning as perceived by higher-education learners. TechTrends: Linking Research and Practice to Improve Learning. 2005; 49(4): $4 \mid-49$

24. Alias N, SaedahSiraj, Rahman MNA, Ujang A, Gelamdin RB, Said AM. Research and trends in the studies of webquest from 2005 to 2012: A content analysis of publications in selected journals. Procedia - Social and Behavioral Sciences. 2013; 103: 763-772.

25. Haralson M, Hoaglund AMY, Birkenfeld K, Rogers B. Using webquests to support pre-service teachers' attitudes toward diversity: A model for the future. Education. 2016; I36(4): 4I3-420.

26. Sanford J, Townsend-Rocchiccioli J, Trimm D, Jacobs M. The webquest: Constructing creative learning. Journal of Continuing Education in Nursing. 20I0; 4 I (I0): 473-479 477p.

27. Drozd M, O'Donoghue J. The use of a webquest to support undergraduate nurses. Teaching and Learning in Nursing. 2007; 2(3): 63-67.

28. University of the Witwatersrand. Wits university revises its mbbch degree admissions policy. 20I6. <https://www.wits.ac.za/media/ wits-university/faculties-and-schools/health-sciences/studentdocuments/undergraduate/Wits\%20University\%20Revised\%20 Health\%20Sciences\%20Admissions\%20Policy.pdf> (November 08 2017)

29. Doyle AC. The adventures of sherlock holmes. George Newnes, Limited, I90I.

30. Articulate Global. Articlate storyline. 2 ed. New York: Articulate Global, Inc; 2015

31. Masters K, Ellaway R. E-learning in medical education guide 32 part 2: Technology, management and design. Medical Teacher. 2008; 30: 474-489.

32. Harris PA, Taylor R, Thielke R, Payne J, Gonzalez N, Conde JG. Research electronic data capture (redcap) - a metadata-driven 
methodology and workflow process for providing translational research informatics support. Journal of Biomedical Informatics. 2009; 42(2): 377-38I.

33. Tomita MR. Methods of analysis: From univariate to multivariate statistics. In: Kielhofner G, editor. Research in occupational therapy: Methods of inquiry for enhancing practice. Philidephia: F.A. Davis Company; 2006: 243-280.

34. Lowry R. "Vassarstats: Website for statistical computation". Vassar College. 200I-2016. <www.vassarstats.net> (I7 August 2016)

35. Kuckartz U. Maxqda I2. I2. I.4 ed. Berlin, Germany: VERBI Software $\mathrm{GmbH} ; 2016$.

36. De Lanerolle I. The future is already here, it's just not very evenly distributed...: Journalism next. Rhodes Journalism Review. 2015; (35): 6-II.

\section{Corresponding author}

\section{Paula Barnard-Ashton}

paula.barnard@wits.ac.za 